\title{
THE WORLD IN A BOTTLE AND THE ARCHEOLOGY OF STAGING: AUDIOVISUAL RECORDING AS REGISTERS OF OPERA PRODUCTION ${ }^{1}$
}

\author{
Mateus Yuri Passos
}

\begin{abstract}
This work focuses on the use of the audiovisual opera recording as a document to analyze contemporary stagings labeled by the German critics as director's theater [Regietheater]. In director's theater, Wagner's total artwork project [Gesamtkunstwerk] achieves a turn in meaning, for the three artistic dimensions of opera - word, music and staging - become different texts. In this paper, we discuss the limitations of audiovisual recording as a register of director's theater opera stagings, as well as filmic resources that allow for a reconstruction of the audiovisual text of such productions with solutions that are often quite distinct from those adopted on the stage. We are interested above all in problematizing the equivalence that is sometimes established between a staging and its recording - especially in the contemporary context of productions that frequently suffer considerable changes and are characterized by the unique aspect of each performance, always full of singular events and relatively autonomous regarding the general plan of the director. Thus, we will discuss problems and solutions of video direction of audiovisual recordings of stagings of the operatic cycle Der Ring des Nibelungen [The Ring of Nibelungo], by Richard Wagner (1813-1883).
\end{abstract}

\section{Keywords}

Opera recording; director's theater; opera staging; Regietheater; Richard Wagner

\begin{abstract}
Resumo
Este trabalho se debruça sobre o uso de gravações audiovisuais como documentos para análise de producções de ópera contemporâneas agrupadas pela crítica alemã sob o termo teatro de director [Regietheater]. Nesse conjunto de abordagens, o projeto de obra de arte integral [Gesamtkunstwerk] de Wagner ganha um novo impulso e significado, pois as três dimensões da arte operística - verbal, musical e visual - deixam de trabalhar em conjunto para a mobilização do drama e passam a constituir textos distintos. Neste artigo, discutiremos as limitações da gravação audiovisual para o registro de encenações operísticas de teatro de diretor, assim como recursos de linguagem de montagem fílmica que permitem reconstruir em texto audiovisual essas producções, com soluções por vezes distintas daquelas adotadas em palco. Interessa-nos, sobretudo, problematizar a equivalência que por vezes se estabelece entre uma encenação e sua gravação - especialmente no contexto contemporâneo de produções que realizam alterações frequentes e se caracterizam pelo caráter único de cada performance individual, sempre repleta de eventos singulares, com relativa autonomia em relação ao plano geral de direção. Para isso, discutiremos problemas e soluções da direção de vídeo em gravações audiovisuais de encenações de Der Ring des Nibelungen [O Anel do Nibelungo], de Richard Wagner (1813-1883).
\end{abstract}

\section{Palavras-chave}

Encenação de ópera; gravação de ópera; Regietheater; Richard Wagner; teatro de diretor

\footnotetext{
' For a more in-depth view on the subject, see doctoral thesis of the author. Available at http://repositorio.unicamp.br/ handle/REPOSIP/269953
} 


\section{INTRODUCTION: DIRECTOR'S THEATER AND THE LIMITS OF RECORDINGS}

In the main room of Hunding's hut, sitting by the table, Wehwalt feels anxious; albeit he has no weapon he must battle his host to death by the sunrise - just today he has killed several members of Hudning's clan who were forcing a woman to marry against herr will. Wehwalt's father, Wälse, had long ago promised him a mighty and sharp sword, which should appear in a moment of need - but there is no sign of it. He despairs and suddenly sees the glint of the metal stuck in the ash tree's trunk. Hunding's wife comes and tells him about the hardships of her life, then both her and him find themselves in love. They decide to flee, and in order to assure their safety they need Notung, the sword and old one-eyed wanderer had long ago stuck in the tree trunk, which only a worthy warrior could pull it out from the trunk. After the woman - who, as he will soon find out, is his twin sister Sieglinde - renames him with his own prime name, a fiery Siegmund rushes to the trunk...

Regarding what happens next, there is strong divergence: Siegmund may stand in a homely medieval hut, in a burgeois mansion of the 1840s, 1940s or even 2000s, in an almost bare space with few furniture with an asseptic, almost laboratorial aspect, or even in a flower field or on the dark and desolated Road of History. According to most versions, he conquers the sword by his own merits and efforts; in other ones, it is Sieglinde who removes the sword from the tree trunk, or even Wotan - both his father Wälse's and the wanderer's true identity - who, while invisible to his sight, puts Notung in his hands; the sword might even appear as if in a vaginal deliver, exiting Siegliende's womb.

The scene we have just described concludes the first act of the opera Die Walküre [The Valkyrie], by Richard Wagner, and is a sample of the variation in the characterization of space and time, as well as the development of action, that has been practiced in opera stagings since the 1960 s when - amid a turbulence of selfquestioning of humankind's deeds and values, e.g. the boom of environmentalism, pacifism and second-wave feminism, as well as the rise of an ever-growing "me culture", simultaneous to a post-modern opposition to the notion of identity (Maffesoli, 2011) - the paradigm of opera staging now known as director's theater [Regietheater] is created in East Germany, promoting displacements in relation to both the libretto and musical dramaturgy and allowing for the director to rise as a creator of relative autonomy.

Today, especially in Germany, opera productions that pursued to follow the setting and action according to the libretto give place to ones in which direction becomes the spectacle itself, sometimes even disputing the audience's attention with the music and the libretto. It often integrates and dialogues with music and libretto: it has proved itself to be a third text, a third dimension for meaning that is composed of all visual aspects of the production, which is the public's contact surface with the drama and its character. This third text is recoded in order to rethink or even restructure the work with an authoral treatment of the staging which creates a unique reading of it, imbued with new meanings. Such practice is known among german critics as Regietheater at least since the 1980s (Ely, 1984) - there have been alternative names such as avancierte Regie [advanced direction] (Garaventa, 2006) and Musiktheater [musical theater] (Eckert, 1995), which signals to 
the coexistence of music and theather as focuses for artistic realization, yet in this paper we will prefer the first denomination, which highlights both the role of the director as a proper author of the staging and the protagonism of the scenic text he or she creates.

The operation conditions of director's theater since its origins in East Germany involve a redefinition of the role of directors - and thus of the work's author -, of its interpreters and also of the critic. One must understand, in first place, that the libretto and the score form together only a potential, ideal work, and an opera is only complete as an artwork when it materializes on the stage. The early approach to opera staging - which has only been understood as one possibility among others when alternative approaches appeared and gradually started to gain importance - aimed to observe the libretto's verbal text, which determined the setting and the action, and the score's multidimensional musical text - which suggested the inner characterization of the characters and situations, unveiled their deepest fellings and, particularly since Wagner, commented upon the action and words. It wished to translate words and music into images, to transport the audience to the space and time of the drama and, in general, to give place to the appreciation of music. Thus, in this perspective, a visual text composed of every still or dynamic scenic element intends to be a transparent medium that does not bring itself to attention while it is enunciated.

In director's theater, however, the creative team of the staging, lead by the scene director, stage designer and costume designer, finds itself with a higher degree if autonomy: thus the artist of materialization abandons a servile attitude regarding the authors of the potential artwork - the composer and the librettist -; first as a political attitude, but also for understanding how limiting it is to understand the work of the director as mere translation, thus renegotiating - or even abolishing - the hierarchy between verbal and musical texts and their visual materialization. While in the early stagings the director conformed to the authors, now two possibilities arise - the director dialogues with the author or, as in more recent productions, the director confronts them - in which it becomes evident that the director also becomes an author, creating a scenic text that interacts with the other two.

One of the milestones of the critical consolidation of director's theater is linguistic in its nature: the creation of the name Illusiontheater [illusion theater] by director Joachim Herz (1989) in the 1960s, while attempting to distinguish "traditional" stagings from Wieland Wagner's "formalist" aesthetics and his own strategings for staging, as well as to characterize them. Albeit a term is intentionally pejorative and alludes to the escapist and alienating dimensions of a staging that intends to be neutral, its adoption was sucessful for not considering Illusiontheater as the standard approach, but one among the many possilibilities for the scenic materialization of opera - which finds an analogue in the creation of the word heterosexual to contrast homosexual, and also cisgender in opposition to transgender, so that "non-standard" sexual orientation or gender identities may be understood not as deviations, but possibilities worth of respect and equality.

Furthermore, the establishment of a concept of illusion theater helps us to define, by opposition, what director's theater is, in general terms: while the former intends to be 
transparent in relation to the potential opera, especially regarding visual characterization and the actions fixed by the libretto, the latter works with different degrees of opacity that make original signifiers less visible and substitute them with new elements. However, in the same manner that "opera" is an all-encompassing word that covers several musical theater genres with very different composition structures - melodramma, opera seria, opera buffa, singspiel, ópera-comique, grand-ópera, Musikdrama, Bühnenfestspiel, Literaturoper, Zeitoper, para-opera etc - the array of possibilities for staging strategies in director's theater is considerably vast: there are several genres or approaches of staging that operate in significantly divergent manners (Parker \& Abbatte, 2012).

The strategies of several directors who got involved with opera staging since the 1980 - e.g. Robert Wilson, Frank Castorf, Ruth Berghaus, Michael Schulz, Anthony Pilavachi, Guy Cassiers, and Carlus Padrissa - were developed in a mainly performatic theater tradition that Hans-Thies Lehmann (1999) names postdramatic theater, which opposes political theayer - in a paradoxically political attitude - through the negation of cause-effect logic, of naturalistic mimesis, of all theater linked to literary formulations, structured upon the fulfillment of a narrative - postdramatic theater considers all of that as authoritarian and illusionist in its attempt to replicate on the stage a positivistic view that could not work in the contemporary world, and also working under the presumption that a (potential) work is equivalent to its performance.

In the postdramatic perspective, the text is only a source, a departure point for the elaboration of a performance, in which the happening prevails over the structuring of a narrativa: the build of tension and its resolution, for example, is annihilated, as well as pathos and continuity. Even the conception of the postdramatic performance itself is developed with a focus on the materialization, its plastic aspects, instead of on communicating ideas, and in a broader sense on the denial of a text that should be communicated.

Frequently the operagoer suffers of an "semiotic overdose": there is an excess of stimuli onstage - not rarely, several simultaneous actions with no hierarchical distinction between them -, an excess of elements of meaning cast over the audience with no clear organizing principle. In the opera, the experience of watching some of these stagings does not differ much from reading James Joyce's Finnegans Wake (2000): one must suspend his or her need for immediate understanding - maybe this is the postmodern version for the notion of "suspension of disbelief" - and let himself or herself shower in the rain of symbols - and later try to reap from it some threads of meaning. The construction of meaning in a scene, in this perspective, would be fulfilled by the public itself - i.e., each operagoer would create the meaning while watching a staging.

Such degree of complexity in the work of these directors in terms of symbolic language demands from the critic and the staging researcher a meticulous apreciation of the scenic resources and strategies. An audiovisual recording is, thus, an important documentation of the production not only for fruition, but also for its reconstitution by future generations - and plays a key role in elevating certain productions to a canonical position. When investigating such stagings in a scholarly perspective, one must admit that film presents an analitical advantage, allowing for the elaboration of less impressinionistic reviews that may even be confronted later on, while also facilitating the access 
to the staging - be it decades later, be it for contemporary opera enthusiasts that are geographically remote ${ }^{2}$. Audiovisual opera recordings reach a larger audience than the usual performances: it is estimated that three years after the film of the Chéreau/Boulez Ring cycle the TV broadcasting of the production was watched by a larger number of spectators than the sum of those who attended the myriad of stagings of the tetralogy around the world since 1876 (Senici, 2010). In this manner, such recordings are potentially the way a considerable portion of the society makes its first contact with Wagner's and other composers' work, and also possibily the only way, in the case of places with no opera theater or that have short seasons with a small number of productions and performances per year - as is the case with most large cities in Brazil.

In this paper, we discuss the limitations of audiovisual recordings for documenting director's theater opera stagings, as well as linguistic resources of filmic montage that allow for reconstructing such productions in audiovisual text through solutions that are often very different from the ones that were resorted to on the stage. We are above all interested in disputing the equivalence that is often established between a staging and its film - particularly in the contemporary context of productions that make changes between seasons, when not between performances, and are characterized by the unique aspect of each single performance, always full of unique events with relative autonomy in relation to the general plan of direction (Fischer-Lichte, 2004).

We will discuss problems and solutions regarding video direction in audiovisual recordings of stagings of Der Ring des Nibelungen [The Nibelung's Ring], by Richard Wagner (1813-1883), a four-opera cycle of which Die Walküres is the second one, together with Das Rheingold [The Rhine Gold], Siegfried and Götterdämmerung [Twilight of the Gods] - the tetralogy, a political alegory articulated from german and norse mythological material, has played a special role in the development of director's theater and its consolidation, serving as groundwork for stage directors to discuss class struggle, ecology, and gender oppression, or even to defy the very notion of articulating ideas onstage.

Our corpus is mainly constituted of audiovisual recordings of the following productions:

- $\quad$ Bayreuth Festival, 19804. Stage direction by Patrice Chéreau and music direction by Pierre Boulez.

- Metropolitan Opera, New York, 1990. Stage direction by Otto Schenk and music direction by James Levine.

- Bayreuth Festival, 1991-1992. Stage direction by Harry Kupfer and music direction by Daniel Barenboim.

- $\quad$ Stuttgart State Opera, 2002-2003. Stage direction by Joachim Schlömer (Das Rheingold), Christoph Nel (Die Walküre), Jossi Wieler and Sergio Morabito (Siegfried), Peter Konwitschny (Götterdämmerung), music direction by Lothar Zagrosek and general concept and supervision by Klaus Zehelein.

\footnotetext{
${ }^{2}$ In this sense, the broadcast of opera recordings in movie theaters and television networks, as well as making them available for home video formats (e.g. VHS, Laserdisc, DVD, and more recently BluRay) or internet streaming services has been quite positive by offering the worldwide public the possibility of watching an abundant amount of stagings.

${ }^{3}$ References to the individual operas will be made by their original titles in German. In the case of the tetralogy as a whole, we will also use in English the expressions "the Ring" and "the Ring Cycle" [Ring-Zyklus], widely known sinonyms for the work.

${ }^{4}$ The year is that when the recording was filmed and not the premiere of the productions.
} 
- Royal Danish Opera (Kopenhagen), 2006. Stage direction by Kasper Bech Holten and music direction by Michael Schønwandt.

- Metropolitan Opera, New York, 2010-2012. Stage direction by Robert LePage and music direction by James Levine and Fabio Luisi.

Apart from those films, we will also mention aspects of the Ring cycle directed by Andreas Kriegenburg at the Bavarian State Opera in Munich (2013) and the staging for the wagnerian opera Die Meistersinger von Nürnberg [The Master Singers of Nürnberg] directed by Katharina Wagner at the Bayreuth Festival $(2008)^{5}$.

\section{THE ARCHEOLOGY OF STAGINGS}

One of the most frustrating aspects in researching opera stagings is the fragmentary constitution of the many other forms of documentating productions in the past photographies, production books, program booklets, reviews in newspapers, magazines and journals, historiographies of stagings. The nonconformity to the impossibility of recovery the totality of past productions may be a completist impulse that is also a symptom of our times, of the age of overarchiving and overdocumentation - with a coverage that reaches from the making of literary, musical and cinematographic works to superfluous private-life events.

The act of consulting such materials implies the archeological ${ }^{6}$ task of reconstructing the productions through the confrontation and comparation of the content of such fragments, which in general are limited to the visual aspects of the productions, although they are at times enriched by the disponibilization of materials related to their artistic conception - interviews with the creative team or essays written by them, sketches of stage and costume designs (when properly accompanied by contextual information) and, in rare cases, even the raw documents for the critical elaboration of a staging?. Such content is often also available in program booklets - which may expand to book form in larger opera companies such as the Bayreuth Festival, the Salzburg Festival and the Bavarian State Opera -, albeit the most commonly found content is a collection of critical essays on the score or the libretto, on the social context of the creation of the opera or even of the librettist's sources ${ }^{8}$.

\footnotetext{
${ }_{5}$ The notation for referencing the stagings will consist of the surnames of the scene director and the music director. Thus, the 1980 recording of the staging of the tetralogy at the Bayreuth Festival, which features the scene direction of Patrice Chéreau and the music direction of Pierre Boulez is cited as the Chéreau/Boulez cycle. In the case of the Stuttgart production, in which a different director worked on each part of the Ring, I decided to use the name of the idealizer and general director Klaus Zehelein, who also speaks for the production in the academia.

${ }^{6} \mathrm{I}$ have decided to use the term in order to compare the task of reconstructing an opera production that was staged years or decades ago to an archeological research which aims to collect the remnants of people of the past in order to understand their culture, their way of life.

${ }_{7}$ An important collection of documents related to the 1970s stagings of the Rings was edited by Mack (1978).

8 In the case of the Bayreuth Festival, the most relevant essays related to the Ring productions from the Neu Bayreuth period, which began in 1951, until the 1976 Chéreau/Boulez cycle were collected in a single volume (Barth, 1980).
} 
Official books of production usually collect a vast number of photographies and thus tend to register mostly the "skin" of the stagings; there are very few that actually collect critical essays, or materials related to the making of the production and the intentions of the creative team. There are some valuable exceptions found in the books of the three Bayreuth Ring productions that were performed between 1976 and 1992 - Chéreau/ Boulez (1976-1980) (de Nussac, 1970), Hall/Solti (1983-1986) (Fay, 1985), and Kupfer/ Barenboim (1988-1992) (Lewin, 1991) - and two scholarly books edited in commemoration of the Zehelein/Zagrosek (Stuttgart) (Klein, 2001) and the Nemirova/Weigle (Frankfurt) Ring cycles (Loebe \& Abels, 2013). The Hall/Solti cycle's book is unique for being a journalistic coverage that registered in third person the creative process of the production, particularly the difficulties faced due to methodological and culture shocks between the creative team and Wolfgang Wagner, the director of the festival at the time - clashes that in part have contributed to the flop of the production, as well as bad choices in the casting and the changes in the expectancies of both the audience and the critics after the early shock with the first social realism productions in Bayreuth in the 1970s. The poor success of the production led Georg Solti to abandon it immediately after the end of its first season in the festival - the conductor was then substituted by Peter Schneider.

There are also books which focuse on the historiography or criticism of the output of individual directors - e.g. Wieland and Wolfgang Wagner, Götz Friedrich, Joachim Herz, Harry Kupfer, Peter Konwitschny, Klaus Zehelein etc - or on the historiography of the stagings at the Bayreuth Festival (Spotts, 1996; Olivier, 2007; and many others), of the stagings of wagnerian dramas in general (Carnegy, 2006; Bauer, 1983; and many others) or the stagings of the Ring in particular (Eckert, 2001; Pargner, 2013; and many others). However, all that material suffers from the same kind of problem: a focus on stage and costume design, with perfunctory and sparse mentions to the actors' and actresses' actions - which may be unavoidable since there is a need for dealing with a high number of productions in an exiguous space and since most of such works deal with stagings before the 1970s (except for Eckert's and Pargner's works). This is a problem because the nerve center of director's theater, in all of its approaches, is precisely the gesture, which plays a deeper role in the characterization of the characters and in establishing links with the libretto and the music -interpreting them, defying them, or even spiting them. The recordings, by their turn, allow us to revisit the productions in a more complete manner - albeit preseting their own limitations.

There are several implications in the use of audiovisual recordings not only as a research instrument, but also for fruition - however I do believe that, beyond some losses, there is a positive final balance. The first implication derives from the very nature of the recording: a performance is something that has an ephemeral character and is destroyed by time, albeit usually preserved in the memory of the audience, and is now captured in an artificial memory that may be consulted by someone who did not witness the original event. This is a problematic pint for critics who advocate the autonomy of the perfomatic dimension, since the filmed version attempts to establish a canonical scenic text for a staging, present itself as its definitive version, and thus denying the fact that no 
performance will be the same as any other before or after it (Risi, 2011) - not only due to deliberate changes, but also due to more subtle differences of higher or lesser impact, that are crystallized in film ${ }^{9}$.

The consultation of other available sources related to the stagings at times allows us to identify changes made by the creative team in the course of a number of seasons. An extra of the Holten/Schønwandt Die Walküre's DVD features a 36-minute conversation between stage director Kasper Bech Holten and the Queen of Denmark Margrethe II in which it is revealed, for exemaple, that one of the most important gestures in the first act of the opera - the moment when Sieglinde (Gitta-Maria Sjöberg) removes the sword for the ash tree's trunk instead of Siegmund (Stig Andersen) - was a change implemented in 2006: at the production's premiere, it was Siegmund himself, as established by Wagner, who was responsible for the deed. Such a change alters substantially the meaning of the scene and, if the recording were filmed in a former season, the version that would be documented in film would not have one of the elements that strenghten the feminist argument of the staging.

In a similar manner, the documentary film Katharina Wagners Feuertaufe [Katharina Wagner's Trial by Fire] - a making of of Wagner's grandgranddaughter's staging of Die Meistersinger von Nürnberg for the Bayreuth Festival - presents an early scenic solution for Beckmesser's (Michael Volle) performance at the matersingers' singing competition. In the libretto, the scribe Sixtus Beckmesser is the incapacity of autonomous creation incarnate - a mastersinger who only duplicates stylistic resources that were catalogued and acknowledge by his peers - while the protagonist Walther von Stolzing - his rival for the hand of Eva Pogner, the daughter of another master - has a raw artistic impulse and, albeit at the end he must compose a meisterlied in the models that are expected by the mastersingers (assisted by one of them, the cobbler Hans Sachs), the song still has innovating beauty and aesthetic features, while Beckmesser resorts to a composition structure that is shallow, conservative and awkward and even to the plagiarism of a nonsense version of Walther's text, which refers to the biblical myth of the creation of the world and to the Eva he is in love with. One of the most striking aspects of Katharina Wagner's staging $^{10}$, however, is Beckmesser's ascenscion from angonist to the moral hero of the story: in that production Walther (Klaus Florian Vogt) is a performance artist who spends the first and second acts making interventions on the scenery with paint and brush, yet during the third act - when he is helped by Hans Sachs (Franz Hawlata) -, he bows to the mastersingers' rules and becomes more and more conservative, to the point of dumping his hipster clothing style - a leather jacket, a yellow shirt and pants with a fleur de lys print - for the formality of asuit and black tie. His course of action in the third act may be

\footnotetext{
${ }_{9}^{9}$ As an example of this, I would like to mention Robert Hale's slip during Wotan's farewell to Brünnhilde in the third act of the Lehnhoff/Sawallisch cycle's Die Walküre. In that scene the Father of Battle must repeat three times the exclamations of "Leb wohl!" ["Farewell"], but Hale skips the first one. The notice of the mistake by the audience, on one hand, spoils the emotional engagement with the performance; on the other hand, in a way it is a relief from the laboratorial and distant atmosphere of the recoding in relation to the experience of watching a performance in person.

10 Featuring stage design by Tilo Steffens, costume design by Michaela Barth and Tilo Steffens, and music direction by Sebastian Weigle.
} 
interpreted as a cooptation by the convenience and traditionalism of the establishment; Beckmesser, by his turn - despite the way he is characterized through words and music - follows the opposite direction and, after being hit by splashes of Walther's paint during the turmoil at the end of the second act, he abandons his formal clothing and engages in an avantgardist role, presenting himself before his fellow mastersingers as a performer artist. At the premiere of the production, in 2007, Beckmesser pulls an apple cart in which there is a naked man, representing Adam, holding his Eva, a sex doll (Figure 1). In 2008, when the recordings for the DVD version were made, Beckmesser drags along a table covered in dark dirt and starts to mold it in the shape of a naked man who then rises from it (Figure 2); Eva is a woman who enters the scene wearing a red dress and is stripped by Beckmesser, while his Adam throws apples at the choir - the spectator of the competition -; completely naked, Eva joins him.

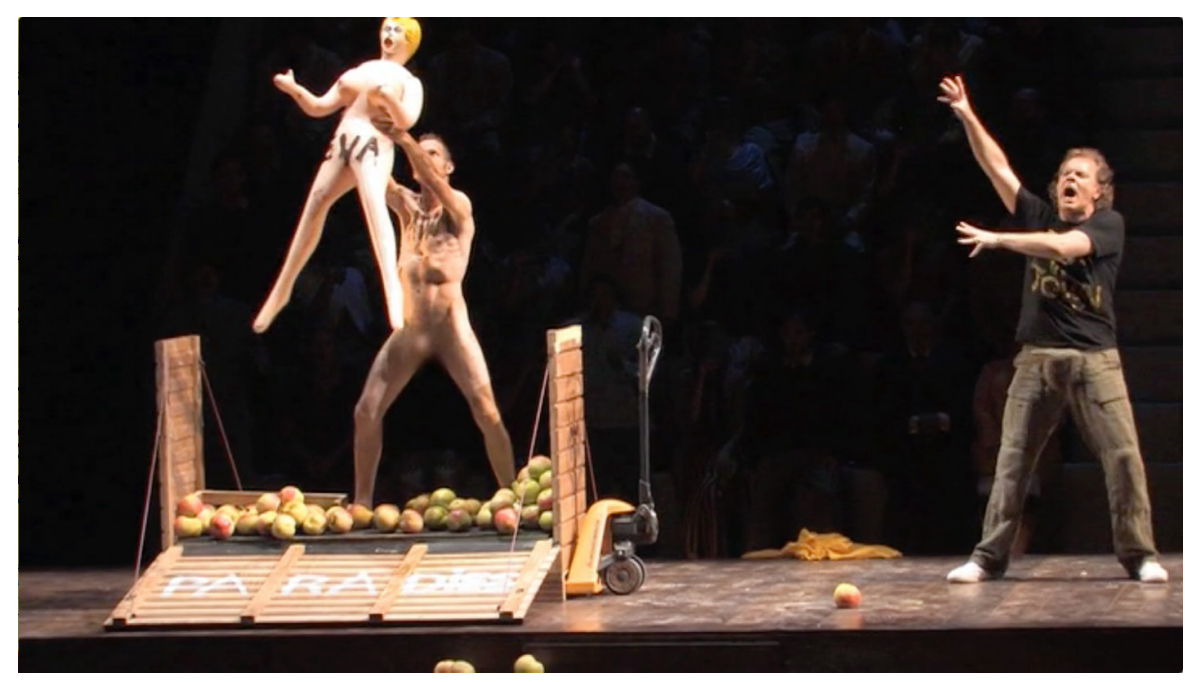

Figure 1: In 2007, Beckmesser (Michael Volle) unveils his Adam and Eve in an apple cart Source: Katharina Wagners Feuertafe - DVD

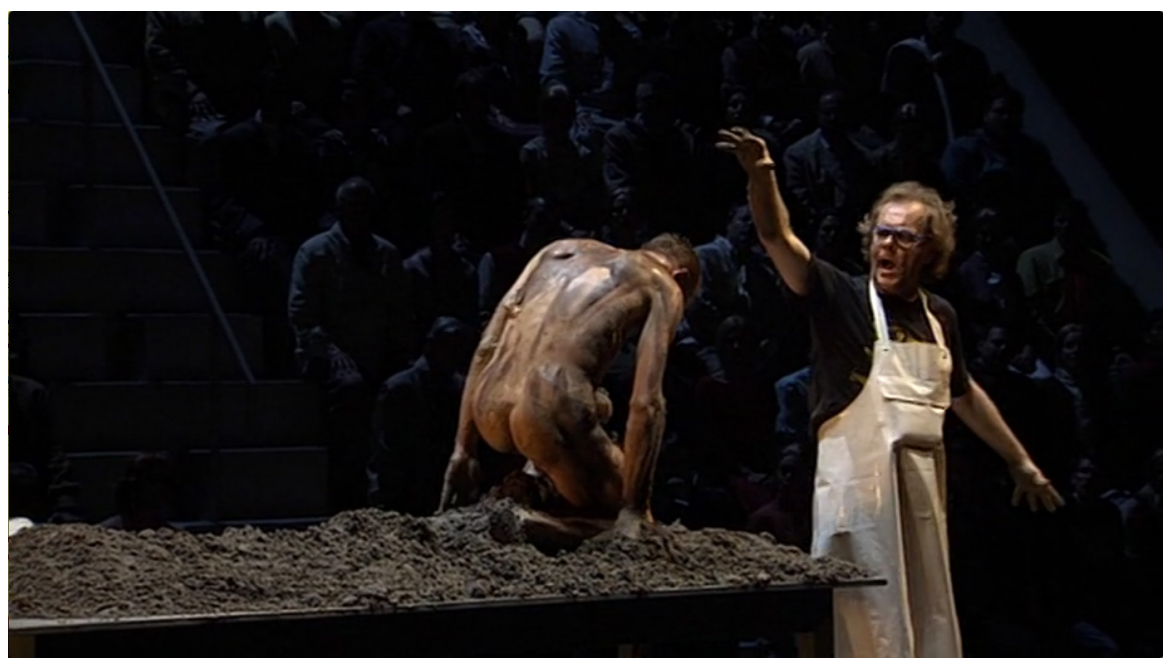

Figure 2: In 2008, Beckmesser (Michael Volle) makes a man rise from the dirt Source: Die Meistersinger von Nürnberg, Bayreuth 2008 - DVD 
Both solutions have several divergent consequences for the characterization of Beckmesser's new role - who intervenes in a more direct way during the second version of the scene and acquires a divine aspect and literally becomes a creator by making a man rise from the dirt -, as well as for the meanings of his performance - in 2008, the woman is not anymore a sex toy, manipulated and carried in the man's hands, and is an autonomous person, with her own actions. Albeit there has been a change in the stage direction, we cannot ignore that during the 2007 Bayreuth Festival the scene with the apple cart and the sex doll was the one the audience has watched, as well as the majority of the critics - who tend to focus their attention on the production that premieres in each year.

Thus, to consider as canon only the performance that was released for home video would imply a reductivist view of the work that was materialized by the creative team, which might even make new changes in the following years - actually, one should avoid considering an audiovisual recording as equal to a performance, since it is not unusual to combine takes from different performances that were recorded in different dates - including dress rehearsals - to compose the film: in such cases, the material that is available in video has never happened as a single performance. There are even differences in the casting that should be taken into consideration - during the first three years of Chéreau/Boulez cycle in Bayreuth, for example, Siegfried was sung by René Kollo, who was substituted in 1979 by Manfred Jung, who was inferior to him as a singer, albeit he was more expressive as an actor.

\section{LIMITING ASPECTS OF SPACE AND FILM}

The insufficiences of the audiovisual recording to capture the in-person experience, however, are not limited to variations between performances of a staging, or even to the performatic dimension: the very materiality of in-person opera differs considerably from the filmed version, since both the film shooting and filmic montage act as another level of mediation between the audience and the production, and together they constitute a fourth text that delimitates the appreciation of the scenic text and in several aspects builds another narrative based on it. The authors of this new textual level are the cameras and the video director.

The camera is an ideal spectator who has special opera glasses that allows it several zoom levels, as well as different points of view, thus giving access to details that are often undesirable when there is an expectancy of maintaining the operatic narrative as an illusion, as is the case of the stagings at the Metropolitan Opera: in the film of the Schenk/Levine Das Rheingold, we can watch Siegfried Jerusalem's Loge as he sweats profusely due to his makeup, while Jonas Kaufmann's Siegmund spits and drools in the LePage/Levine Die Walküre. However, the viewer of a recording has no autonomy to decide where he or her is going to focus his or her attention: it is the cameras and the montage that determine in our place what shall be seen, and the audience has a more passive role.

This is a relevant problem, especially regarding productions after the 1990s, when the postdramatic paradigm grew stronger, when it became common to have stagings 
featuring scenes with a myriad of simultaneous events, several of them having some importance: as an example I would like to mention the end of the first act of the Siegfried staging directed by Andreas Kriegenburg and conducted by Kent Nagano, which is part of the cycle that has premiered in Munich in 2012. In that scene, Siegfried forges Notung anew, the sword that belonged to his father and was split into pieces by Wotan in Die Walküre, and the nibelung Mime prepares a somniferous drink that he will try to use to kill Siegfried in the following act. In the score, Wagner makes clear the moments when the former or the latter are on the foreground, but in Kriegensburg staging this hierarchy is broken apart and both are very active all the time - Siegfried builds and operates a huge pair of bellows with the help of some extras, while other extras are used as guinea pigs for Mime to test different formulae of the poison, and there are yet other groups of extras who act independently of both characters. A scene composed in such manner will certainly be castrated by the narrow visual field of an audiovisual recording, since it would be not possible to portray every action in a satisfactory way. An archive film of the Bavarian State Opera from $2012^{11}$ has solved this by using a long shot that fit the whole stage in the screen; this is, however, a strategy that does not work well in terms of audiovisual fruition: there is a huge difference between watching the stage in person and watching a still stage in film - in the latter case, we miss the depth perception and even the engaging with the action onstage, since the actors look tiny and deprived of individuality.

The strategy that has become a standard for filming opera (Citron, 2000) involves the use of full, medium and american shots to record the scenic narrative in its normal progress, and close-ups and extreme close-ups to highlight the expression of emotions, with the occasional use of a long shot only to contextualize the space where the action happens - or to convey actions that involve movement through the full length of the stage. The alternance of takes of different shots and points of views varies considerably depending on the recording: in the Chéreau/Boulez cycle, for example - when the strategies for filming opera performances were still under development - there is a more frequent use of long shots than in later recordings; as demanded by Kupfer, his staging for the Bayreuth Festival was filmed always with a full-front point of view that would simulate the audience's point of view; in the opposite direction, Uffe Borgwardt, the video director of the Holten/Schønwandt cycle film, has planted cameras in the furniture onstage - which were of a lower resolution than the full-front cameras - that made possible to film the action in angles that would be impossible for the audience to see, and during the montage he has opted for alternating points of view with considerable frequence - which is often very uncomfortable for the viewer, in special because the display of an action is interrupted in order to show another event that was happening onstage at the same time.

\footnotetext{
"Displayed during Jürgen Schläder's three-day seminar at the Capriccio-Saal of Munich's Nationaltheater that was meant to be a companion to the performances of the Kriegenburg/Nagano cycle during the summer festival of the Bavarian State Opera in July 2013.
} 


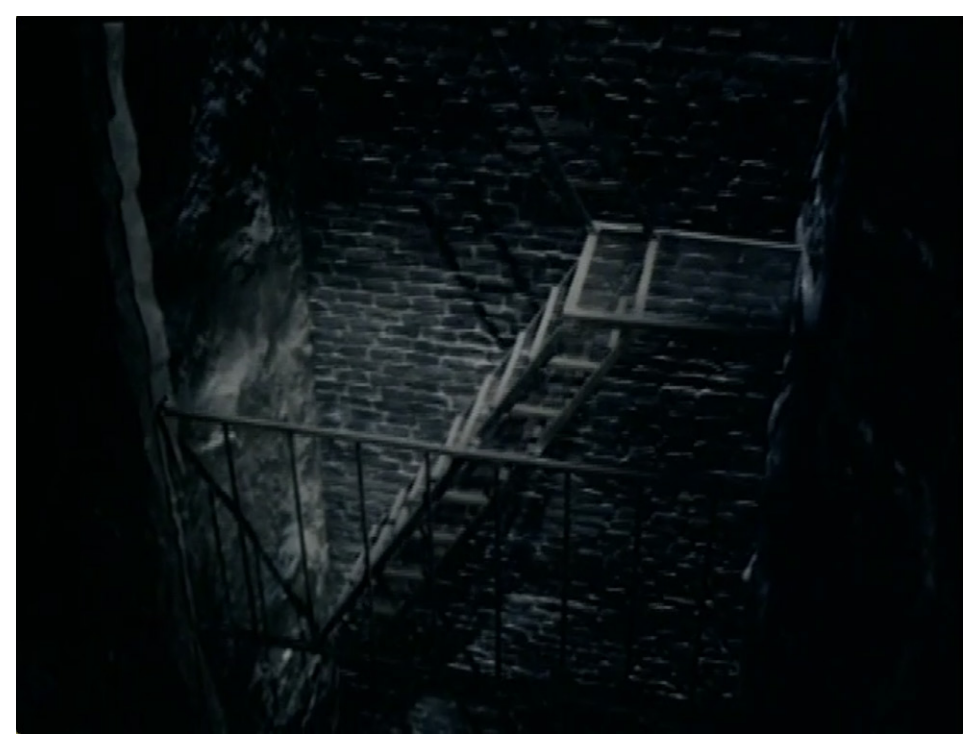

Figure 3: The passage through a staircase represents Wotan's and Loge's descent to Nibelheim Source: Das Rheingold, Bayreuth 1980 - DVD

There are also cases in which filmic montage is used to insert footing that does not correspond to what was visually available to the audience during the performnace - this happens mostly during instrumental passages, especially in the overture of an act or in transitions between scenes, when the curtains are closed or the stage is immersed in darkness for a long time. In the film of the Lenhoff/Sawallisch cycle - as well as in the Schenk/Levine cycle - the visual dimension of the transitions is occupied by an animation simulating the waters of the Rhine river - between the first and second scenes of Das Rheingold - or by moving smoke that appears in different colors: apparently there is a fear of the viewer will feel bored and the video director prefers to occupy the screen why some image, even if it is abstract and disconnected from the content of the drama. In the case of the Chéreau/Boulez cycle the solution the video director found was to show animations that simulated the change of scenery in the backstage - which allows for a new type of vantage point for the viewer, this time penetrating behind the curtains of Bayreuth -, or even the Wotan's and Loge's descent to Nibelheim (Figure 3), which is represented by a staircase, this time integrating the scene transition to the narrative of the drama by adding information that is actually related to the production.

The strategy in the film of the Holten/Schønwandt production is multifaceted: on one hand, there is an effort in contributing for the narrative of the staging by showing footage in which Brünnhilde (Irene Théorin) roams through a library in order to browse Wotan's archives (Figure 4), or even slow-motion reprises of past scenes' excerpts - the framing narrative in this production establishes that all events until the third act of Götterdämmerung are flashbacks in the valkyrie's mind; however, sometimes the film shows takes of the orchestra playing, an expedient that is also used in the films of the Zeheilen/ Zagrosek and Pilavachi/Brogli-Sacher cycles, and is in general very common in audiovisual opera recordings. It is also a debatable artifice, since it disrupts the textual continuity of the staging - it is especially problematic for productions of wagnerian operas, if 
we are to observe the composer's wish that the audience should focus exclusively on the drama onstage, which led to the invention of a special pit for the theater he designed for Bayreuth, where the orchestra is fully hidden from the spectators ${ }^{12}$.

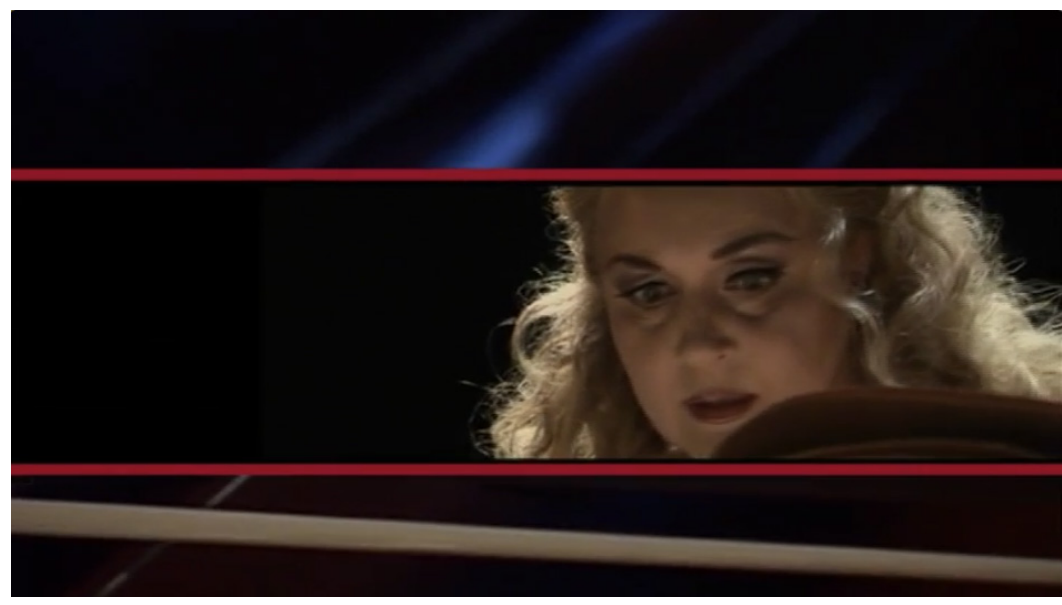

Figure 4: In the transitions between scenes, Brünnhilde (Irene Théorin) browses the faimily archives Source: Das Rheingold, Kopenhagen 2006 - DVD

Filming may also produce other kinds of noise in relation to the staging it is documenting. One of the most flashy visual aspects of the Kupfer/Barenboim cycle was the use of laser beams, in particular to symbolize the fire that surrounds the rock where the sleeping Brünnhilde lies in Die Walküre and Siegried and the Rhine river in Das Rheingold and Götterdämmerung - in this case, however, it was necessary to change the beam color from dark blue to a phosphorescent green, since the light frequency that was originally used would not appear in video as a continuous beam (the effect the stage designer had intended), but an intermittent one: the change, however, matches the setting of the staging, a post-apocalyptic world devastated by a nuclear catastrophe ${ }^{13}$. The cameras are also inept in recording video projections onstage, which have become common in the last decade, for example, to simulate the fire that surrounds Brünnhilde's rock, and are an essential feature of the LePage/Levine/Luisi cycle, in which all the scenery is formed through image projection over a set of rotating aluminium planks - in several takes in which there are medium and close-up shots, the projection pales and sometimes even disappears in constrast to stage lighting, and thus its effect is ruined.

We should mention, however, that there are moments when the use of several cameras and of filmic montage contribute in a rather positive way for the emulation of the scenic text as it was in loco, in particular in the first scene of the Holten/Schønwandt Götterdämmerung and during the third act of the Konwitschny/Zagrosek Götterdämmerung. In Kopenhagen, the film starts with the orchestra in the pit and soons moves up to the central part of first row in the stalls, which receives direct lighting, albeit the audience

\footnotetext{
${ }_{12}$ However it is evident, when discussing director's theater productions, that for better or worse the author's intentions are not required to be part of the preoccupations in the minds of the creative team anymore.

13 The production premiered in 1988, two years after the explosion of the fourth reactor of Chernobyl's nuclear power plant.
} 
seems to not be bothered by that; a corpulent woman wearing a red wig (Susanne Resmark) calls the attention of the man sitting next to her to the light and is kindly ignored so that he could concentrate on the opera - then, she sings: "Welch Licht leuchtet dort?" [what light is that shining there?]. The second norn (Hanne Fischer) appears a few rows behing (Figure 5) and the third (Anne Margrethe Dahl) in one of the boxes. The placing of interpreters amidst the audience - where they act as opera houses habitués, newspaper critics and members of wagnerian societies - is a solution that is very hard to reconstruct on film - especially when, as it is the case, the singer/actresses are distant from each other -, but the strategy of Uffe Borgwardt's montage, by using strategically placed cameras and quick alternances of points of view, has contributed to recreate the scene with a good flow.

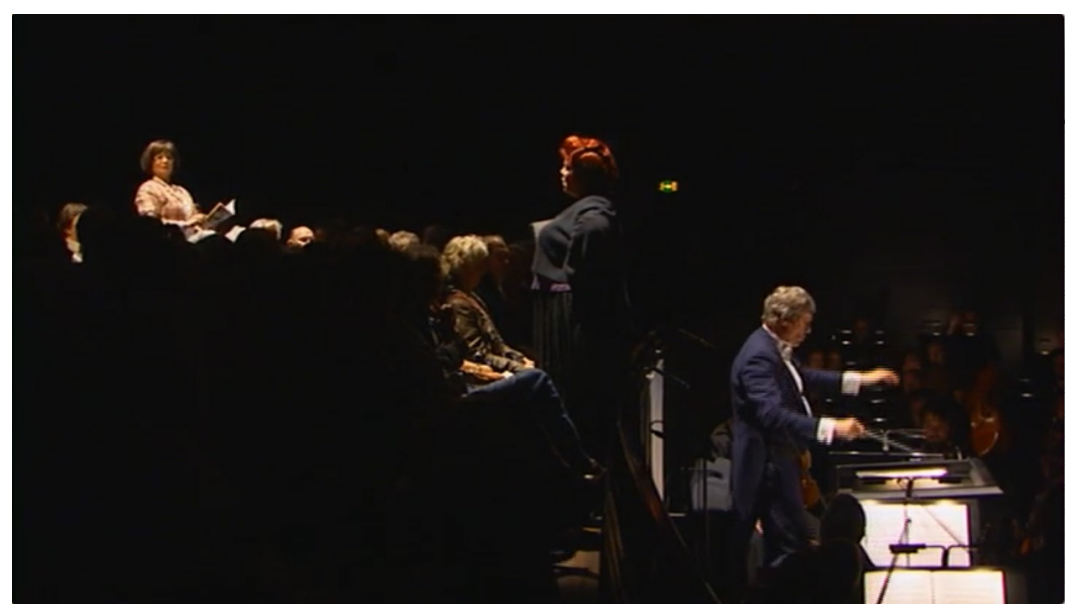

Figure 5: The norn scene is staged amidst the audience of the Royal Danish Opera Source: Götterdämmerung, Kopenhagen 2006 - DVD

A very clever use of shots and montage was also necessary in the case of Peter Konwitschny's Götterdämmerung in Stuttgart, in the beginning of the second scene of the third act - when Siegfried (Albert Bonnema), unable to find his horn, ask a french horn player in the orchestra to play in his stead, in order to answer to the calls of Gunther and Hagen's hunting group - and during the whole third scene of the act since Brünnhilde's (Luana DeVol) entrance onstage, when the lights of the theater suddenly are light up, and all the characters onstage become aware that they are singers/actors in the performance of an opera. Video director's Hans Hulscher solution consisted in alternating shots of the actors onstage with shots that showed the audience that was watching them, which is especially effective at the moment when the lights turn on and the actors notice the audience and contemplate it in awe - the montage allows for a narrative reconstruction of the interaction between interpreters and their public - and in using shots long enough to show simultaneously the stage and the first rows of the audience in the stalls, thus avoiding that the viewer would become totally immerse again in the action onstage, which would result in a loss of the break of the fourth wall effect. 


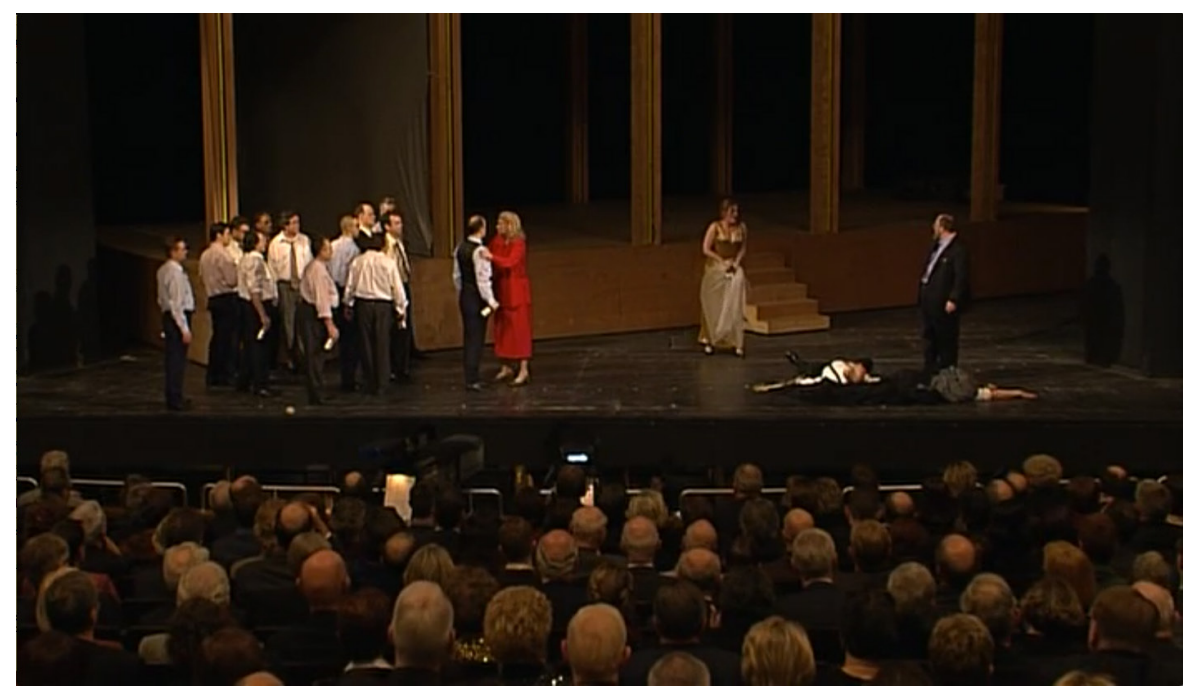

Figure 6: The use of long shot is an attempt to recreate in video the breaking of the fourth wall in Konwitschny's staging

Source: Götterdämmerung, Stuttgart 2003 - DVD

Notwithstanding, the framing and montage of these set of shots work only as an attempt to compensate for an unreachable experience, since the in-person effect is impossible to duplicate in film - the suprise and discomfort due to the lights being suddenly turned on, the exchange of looks with the puzzled characters, in the same way that the audience was gazed upon by the proletariat that survives the catastrophe at the end of the Chéreau/Boulez cycle.

\section{CONCLUSION: THE WORLD IN A BOTTLE}

Now we move on to the last aspect we are deprived of when watching an audiovisual recording of an opera: the community experience, which may be a strong reason for the culture of opera being kept so alive in Germany and world centers. Reading the libretto, the score or the program before the performances or during the intermissions - which some may also enjoy to finally sit after stading for more than one hour to watch the production -exchanging opinions on the production with friends or strangers, walking in the foyer or in the garden - where it is possible to picnic, in the case of Bayreuth -, contemplating the busts of composers and artistic directors of the house, going to the theater store of to the cafeteria, getting through the speakers of the theater, as it has happened in July 2013, the news that Klaus Florian Vogt, who would play and sing the title role in Lohengrin, was sick and would be substituted by Jonas Kaufmann, followed by loud and enthusiastic applause - all this is part of the experience of an opera spectacle.

Werner Herzog had found a formidable expression to define the art of opera staging: "the transformation of the world into music" [Die Verwandlung der Welt in Musik], the title of his documentary film on the backstage of productions of the Bayreuth Festival in 1993 - an expression that is particularly true regarding wagnerian dramas, in which there is a yearning for capturing and expressing several dimensions - sensorial, 
emotional, ethical, political - of the experience of the world. In the audiovisual recording of such productions, however, all we have access to is the world in a bottle, enclosed by the screen, a representation that is subtly or severely distorted by the medium, as we have seen in the course on this paper.

In a conventional opera theater we have several possibilities of seats which price varies according to comfort, proximity to the stage and quality of the view offered, fluctuating from $€ 7.50$ to watch the performance while standing on the upper gallery, not unusually with a partial view of the stage, or even with no view at all, to $€ 200$ for the best seats in the stalls $\mathbf{s}^{14}$. Each seat offers a different experience for the same performance: it is possible, for example, to be on a balcony and have part of the stage out of view, which means that the spectator will spend some minutes wishing for the actors to move at least to the center and forefront of the stage and still, in spite of this drawback, be able to see certain elements of the scenery - and possibly some events - that are hidden from the spectators that are right in front of the stage. There is a somewhat different situation in opera houses that have indoor amphitheaters - which is the case of the Bayreuther Festspielhaus, which was very innovating regarding opera theater architecture, and the Prinzregententheater in Munich, which borrowed heavily from the wagnerian temple.

In the case of audiovisual recordings, the limitations of each seat are substituted by a vantage point that is closer to the stage - and thus closer to the scenery and actor - than it would be possible for any member of the audience. There is an undeniable emotional detachment in relation to the production - which is produced even by the nature of the screen, which in opposition to the benjaminian aura (Mendonça, 2010) -, particularly at those moments when the ambience of the theater is in some way part of the scenic text: the suspension of disbelief is broken and the viewer is remined that he or she is not watching the performance of an opera, but a recording of a performance, which point of view is mediated by cameras and which narrative is reconstructed through filmic montage. The same happens regarding the curtain calls, which lose most of its significance on filme, since the viewer cannot participate in it with applause or boos - albeit there are people who do it in live cinema broadcastings such as the ones offered by the Metropolitan Opera through its MetLiveHD project. The curtain calls in an audiovisual recording may even gain a new meaning, allowing for evaluating the reception of the performance and the interpreters.

To consider an audiovisual recording as equal to the totality of a staging or performance is certainly naive and deceitful. However, it is also a problem to consider the live, in-person performance as the only possible way to understand and comprehend the production - after all, since it is unfeasible to attend every performance, a critic will surely have to be satisfied with only one, or a small number of performances, and while analyzing them will also be limited to this sample - in the same manner as he or she, unable to duplicate the experience of a performance, will write about it with a focus on what was possible to be grasped during the session; everything that escapes his or her attention and memory and will be lost and irrecoverable. The audiovisual recording is thus the

\footnotetext{
${ }^{14}$ I am using here, as an example, contemporary prices at the Nationaltheater in Munich.
} 
most satisfactory instrument we have in the archeological endeavor of recovering the artistic achievements of the past.

Traduzido por Mateus Yuri Passos

\section{FUNDING}

This paper is an output of a research funded with a PhD fellowship from the Brazilian National Council for Scientific and Technological Development (CNPq, Brazil, ID 141241/2011-0) and a fellowship for a one-year stay in Munich, Germany from the Coordination for the Improvement of Higher Education Personnel (CAPES, Brazil, ID 18298-12-5).

\section{BibliogRAPHIC REFERENCES}

Barth, H. (Ed.) (1980). Bayreuther dramaturgie: Der Ring des Nibelungen. Stuttgart/Zürich: Belser.

Bauer, O. G. (1983). Richard Wagner: The stage designs and productions from the Premières to the present. New York: Rizzoli.

Carnegy, P. (2006). Wagner and the art of the theatre. New Haven: Yale University Press.

Citron, M. J. (2000). Opera on screen. New Haven: Yale University Press.

Eckert, N. (1995). Von der oper zum musiktheater. Berlin: Henschel.

Eckert, N. (2001). Der Ring des Nibelungen und seine Inszenierungen von 1876 bis 2001. Hamburg: Europäische Verlagsanstalt.

Ely, N. (1984). Und so haben wir das regietheater in der oper. In N. Ely \& S. Jaeger (Eds.), Regie Heute: Musiktheater in Unserer Zeit (pp. 225-237). Berlin: Quadriga.

Fay, S. (1985). The Ring: Anatomy of an opera. Dover: Longwood Press.

Fischer-Lichte, E. (2004). Ästhetik des performativen. Frankfurt: Suhrkamp.

Garaventa, A. (2006). Regietheater in der oper. München: Martin Meiden Bauer.

Herz, J. \& Kobán, I. (Eds.) (1989). Theater-Kunst des erfüllten augenblicks. Berlin: Henschel.

Joyce, J. (2000). Finnegans wake. London: Penguin.

Klein, R (Ed.). (2001). Narben des gesamtkunstwerks: Wagners Ring des Nibelungen. München: Wilhelm Fink.

Lehmann, H. T. (1999). Postdramatisches theater. Frankfurt: Verlag der Autoren.

Lewin, M. (Ed.) (1991). Der Ring Bayreuth 1988-1992. Hamburg: Europäische Verlagsanstalt.

Loebe, B. \& Abels, N. (Eds.) (2013). Schafft neues!... Richard Wagner in Frankfurt. Frankfurt: axel dielmann-verlag.

Mack, D. (Ed.) (1978). Theaterarbeit an Wagners Ring. München: Piper. 
Maffesoli, M. (2011). Pós-modernidade. Comunicação e Sociedade, 18, 21-25.

Mendonça, P. F. X. (2010). Objectos, poder e oculto - Sobre a experiência do ecrã. Comunicação e Sociedade, $17,51-66$.

Nussac, S. (Ed.) (1980). Der “Ring” Bayreuth 1976-1980. Berlin: Kristrall-Verlag.

Olivier, P. (2007). Der Ring des Nibelungen in Bayreuth von den Anfängen bis heute. Mainz: Schott.

Pargner, B. (Ed.) (2013). Von der welt anfang und ende: "Der Ring des Nibelungen in München". Leipzig: Henschel.

Parker, R. \& Abbate, C. (2012). A history of opera: The last four hundred years. London: Allen Lane.

Passos, M. (2015). Eram os deuses magnatas? A reconstrução textual de Der Ring des Nibelungen pelo teatro de diretor. Tese de Doutorado, Universidade Estadual de Campinas, Brazil. Retrieved from http:// repositorio.unicamp.br/handle/REPOSIP/269953

Risi, C. (2011). Opera in performance: in search of new analytical approaches. The Opera Quarterly, 27, $283-295$

Senici, E. (2010). Porn style? Space and time in live opera videos. The Opera Quarterly, 26, 63-80.

Spotts, F. (1996). Bayreuth: A history of the Wagner Festival. New Haven: Yale University Press.

\section{BIOGRAPHICAL NOTE}

Mateus Yuri Passos is a postdoctoral researcher at the Faculdade Cásper Líbero (São Paulo, Brazil) and is the associate editor of the Revista Comunicação Midiática journal. He holds a PhD Degree in Theory and History of Literature (Universidade Estadual de Campinas - Campinas, Brasil).

E-mail: mateus.passos@gmail.com

Faculdade Cásper Líbero

Avenida Paulista, 900, 01310-940 São Paulo-SP, Brazil

* Submitted: 01-10-2016

* Accepted: 23-01-2017 